IZA DP No. 9295

Dismissal Laws in Australia:

Reforms and Enforcement by Labour Courts

Benoit Pierre Freyens

Xiaodong Gong

August 2015

Forschungsinstitut

zur Zukunft der Arbeit

Institute for the Study

of Labor 


\title{
Dismissal Laws in Australia: Reforms and Enforcement by Labour Courts
}

\author{
Benoit Pierre Freyens \\ University of Canberra \\ and Australian National University \\ Xiaodong Gong \\ University of Canberra \\ and IZA
}

Discussion Paper No. 9295

August 2015

\author{
IZA \\ P.O. Box 7240 \\ 53072 Bonn \\ Germany
}

Phone: +49-228-3894-0

Fax: +49-228-3894-180

E-mail: iza@iza.org

Any opinions expressed here are those of the author(s) and not those of IZA. Research published in this series may include views on policy, but the institute itself takes no institutional policy positions. The IZA research network is committed to the IZA Guiding Principles of Research Integrity.

The Institute for the Study of Labor (IZA) in Bonn is a local and virtual international research center and a place of communication between science, politics and business. IZA is an independent nonprofit organization supported by Deutsche Post Foundation. The center is associated with the University of Bonn and offers a stimulating research environment through its international network, workshops and conferences, data service, project support, research visits and doctoral program. IZA engages in (i) original and internationally competitive research in all fields of labor economics, (ii) development of policy concepts, and (iii) dissemination of research results and concepts to the interested public.

IZA Discussion Papers often represent preliminary work and are circulated to encourage discussion. Citation of such a paper should account for its provisional character. A revised version may be available directly from the author. 
IZA Discussion Paper No. 9295

August 2015

\section{ABSTRACT}

\section{Dismissal Laws in Australia: Reforms and Enforcement by Labour Courts}

The paper analyses the arbitration of dismissal disputes by Australian labour courts over a 15 years' time span characterized by two major legal reforms to unfair dismissal statutes. We isolate two channels by which we think the social values of the Federal government affected the decisions of the courts: (i) through changes to established rules (the legal standards guiding decisions) and (ii) through labour court appointments (changing the composition of decision-makers). We study these two questions by analysing the probability of plaintiffs' victory in Australian labour court, using a panel of 81 judges and 2,223 decisions. We test for and subsequently exploit the randomized matching of labour court judges with unfair dismissal cases. We also test for and address the Priest-Klein selection effect, which is known to potentially invalidate analysis of trial cases. Using several model specifications we find significant effects from both channels: statutory reforms and judges' work background have strong and significant effects on case outcomes.

JEL Classification: J52, K31, K41

Keywords: $\quad$ unfair dismissal laws, judicial backgrounds, case outcomes

Corresponding author:

Xiaodong Gong

NATSEM

University of Canberra

ACT, 2601

Australia

E-mail: xiaodong.gong@canberra.edu.au 


\section{Introduction}

In this paper we analyse the arbitration of dismissal disputes by Australian labour courts over a long period of time characterized by two major legal reforms to unfair dismissal statutes. In this endeavour, our interest is to test for government influence in the decisions of the courts administering unfair dismissal disputes. More particularly we want to test whether the social values of conservative and progressive governments have any bearing on courts' outcomes. Workplace justice is an ideologically charged concept and labour courts operate in a context in which judicial decisions rely as much on social values as on established rules Brennan (1996). Social values ('efficiency', 'freedom', or 'fairness') emerge from the day-to-day projection of strong ideological arguments over workers' rights to job security, business freedom to adjust or discipline their workforce, and appropriate levels of government intervention in labour markets. By contrast, established rules about employment protection reflect a longer term evolution of acceptable norms and standards embodied either in in case law or in statutory law (unfair dismissal laws).

Unfair dismissal laws aim at striking a balance between workers' demand for employment security and firms' demand for flexible workforce adjustment and discipline. Because these demands are to a very large degree mutually exclusive ${ }^{1}$, the resolution of dismissal disputes through public arbitration institutions is controversial and prone to ideological debate and use of value judgements ${ }^{2}$. Furthermore, judicial ideology is likely to play a bigger role in labour courts than in common law courts. Australian labour courts are 'quasi-courts' (a hybrid between a court and a public administration) and they operate with weaker standards than Federal (common law) courts. By legislated statute, labour court judges arbitrating unfair dismissal disputes apply a 'balance of probabilities' standard to their decisions, which is much weaker than the 'beyond reasonable doubt' standard required of common law judges in Federal courts. Even in very complex cases, it is sufficient that the judge in charge of the case believes that the balance of probabilities weighs slightly more in favour of one of the parties to make a decision conforming to that standard. In this context, the social values and work background of a labour court judge could play a much bigger role than in common law courts.

With so much judicial discretion at play and the control of such an ideologically contested ground at stake, it is unsurprising that governments of different political persuasion should attempt to tip the balance of workplace justice towards their preferred policy stance and social values. Government 'activism' could operate through two channels: (i) direct amendments to statutory laws, which affect established rules and judge's discretion to administer workplace justice; and (ii) changes in the composition of labour courts, which affect the development of case law or the way in which established rules are interpreted and applied to case decisions.

\footnotetext{
${ }^{1}$ There are various arguments that unfair dismissal laws achieve much more than merely providing security to workers and imposing adjustment costs to firms. For instance, in large organisations, the laws may help improve productivity by correcting information asymmetries deterring workers' investment in firm-specific skills, or in adoption of new technologies Gavin (1986), Emerson (1988), Buechtemann (1993)

${ }^{2}$ Although it is not the main theme of our article, it is worth noting that there is little consensus in the academic literature on the social benefits and economic impacts of employment protection laws. There has been considerable research interest in the U.S, Europe and Australasia about the labour market effects of these laws (on employment levels, productivity, wages, job transition, unemployment duration, minority groups, etc.). Good reviews of this literature can be found in Bertola (1999), Addison and Teixeira (2003), Verkerke (2009), and Skedinger (2010).
} 
The former captures changes in the context in which decisions are made, whereas the latter represents changes in the composition of the set of decision-makers.

If the judicial processes of labour courts are not value-free, a judge who has insufficient evidence to decide a case based on established rules may rely on her own ideological beliefs to issue a decision. It has long been believed that case outcomes are indeed influenced by judges' characteristics, especially their ideological and work backgrounds. For example, a 'legal realism' view predominantly developed and tested in the United States (US) holds that judges often behave as activists, deviating from independent and impartial rulings in the pursuit of strategic interests. An extensive legal and political science literature empirically examines this issue. However, most of this evidence is US-based, unrelated to labour law, and limited to cases for which the court publishes an opinion (mostly appellate opinions).

We address the first question (effects from reforms to established rules) by quantifying the degree to which the decisions of judges may have adjusted to several reforms to Federal unfair dismissal laws that took place in Australia over the last 20 years. We address the second question (compositional effects from ideological appointments) by estimating the extent to which judges' political and work backgrounds determine the outcome of arbitration cases (ie, independently of direct changes to established rules). Since it is reasonable to believe that the processes by which labour courts formulate judicial decisions are unlikely to be value-free, there is a significant probability that judicial decisions may at least partly draw from these social values. If some or all of judicial appointees act through their decisions as indirect vectors of their appointing party's ideology then the arbitration of dismissal disputes presents an ideal field of study to test for the extent of political influence in the rulings of appointees.

One of the major hurdles to overcome in our endeavour is addressing the selection effect: cases adjudicated in courts are unlikely to be a representative sample of all cases lodged. The influential Priest and Klein (1984) study argues that tried cases are the most complex ones: since weak and strong cases are weeded out through conciliation and settlement of disputes, only those with inconclusive evidence and claims remain. Those claims that proceed to a hearing are therefore characterised by divergent expectations of the parties due, at least in part, to the unpredictability (complexity) of the case. If this assertion is correct, a legal regime more favourable to dismissed employees leads to more settlement favourable to the claimants and vice versa if the legal reforms favour employers, but it does not affect the most complex cases reaching a trial. When the parties are able to predict the result of the verdict sufficiently accurately (i.e., when their prediction error goes to zero), and under certain conditions, the really complex cases still reach courts with a 50-50 probability of success. In this context, changes to the law and/or judicial backgrounds of the judges are irrelevant for case outcomes. The Priest-Klein model has been tested in a large number of litigation settings, drawing support (e.g., Kessler et al. (1996)) and criticism (e.g., Wittman (1988)), but its influence is such that inferences from any empirical association between measures of legal change and changes in the win-loss percentage have often been met with scepticism by researchers. Recent research suggests nonetheless that much information can nonetheless be inferred from trial cases about the effects on judicial decisions of legal changes and court composition. In particular, Klerman and Lee (2014) show that when there exists information asymmetry between the disputing parties, or when their prediction error is sufficiently large (which is often the case in reality), even if there is a selection effect a la Priest \& Klein, inference can still be made over the influence of judges' social values or changes in established 
rule on the verdicts. The loose 'balance of probabilities' standard in force in Australian labour courts is likely to meet his criterion (absence of a clear judicial standard), enabling us to justify the use and analysis of trial cases to address our research questions.

A second hurdle to overcome in our quest to isolate reforms and compositional effects in arbitrated decisions is the potential presence of a second selection effect: if litigants know in advance which judge will decide their case they may pull out (or press on) when they think the identity of the judge lowers (raises) their chance of success. Of further concern still, if judges could cherry-pick the dismissal cases they would prefer to arbitrate, they may themselves selfselect into (or out of) some types of cases. Either way, our identification strategy would be compromised. In order for us to to successfully and convincingly link a judge's characteristics with her decisions, it is essential that the set of cases that she decides has on average the same characteristics as the cases faced by other judges. In the third section of this paper we explain how we test for the randomised allocation of cases to judges, and the conclusions we draw from this exercise.

Section 2 of our paper offers background information about the functioning of Australian labour courts, unfair dismissal applications and their allocation to judges (or commissioners ${ }^{3}$ ). We also present the underlying statutory laws and two major reforms to these laws, legislated in 2005 and 2008 respectively, and implemented in 2006 and 2009. Also discussed in Section 2 is the influence of potential Priest-Klein selection effects and how we address this issue. Section 3 presents our data sources and characteristics, some descriptive analysis of the data, and the results from our randomised experiment tests. In Section 4 we present our panel data methods and specifications, and then discuss the results of our analysis of contextual (legal reforms) and compositional (judges' profiles) effects in judges' decisions. Section 5 concludes the article.

\section{Institutional background and related literature}

\subsection{Labour courts in Australia}

The Fair Work Commission (FWC) is the labour court in charge of conciliating and arbitrating a range of labour market disputes in Australia. It is divided into ten panels, one of the most prominent being the Termination of Employment Panel (TEP). Judges of the TEP (referred to as 'commissioners') are appointed on a permanent full-time basis until they reach 65 years of age. They are appointed by the Governor-General of Australia on the recommendation of the government of the day. Nominations for labour court appointment are based on candidates' demonstrated expertise in workplace relations, labour law, business management, knowledge of the workings of specific industries, etc. Judges are therefore selected from a diverse range of occupational backgrounds, but most are lawyers and attorneys (others are former businessmen, human resources managers, industry experts, union delegates or civil servants). Other FWC panels (e.g. Industrial Action, or Minimum Wages) allocate cases to judges on the basis of their industry-specific background but this is not the case for the TEP where case allocation is independent of the specific background of the judge and operates

\footnotetext{
${ }^{3}$ Australian labour courts are statutory agencies of the Federal government. To reflect their hybrid nature (court + public service agency), labour courts judges are referred to as 'commissioners'. We will use 'judges' and 'commissioners' interchangeably hereafter in this paper.
} 
through an entirely random process. At the start of each month, the Head of the TEP fills a roster, which matches judges to cases through a lottery ${ }^{4}$. There are a few (minor) exceptions to this rule. In the Western Australian representation of the TEP cases are allocated 'off the clock' to whichever judge is available at that precise moment. There are also no permanent representations of the TEP in Tasmania and the Northern Territory. All Tasmanian cases in our data are decided by the same commissioner (from the State of Victoria). Matters in the Northern Territory are allocated to the member on the roster for the month in which a particular file is listed. Matters will occasionally be allocated to members in states other than where the parties are located. This includes files requiring arbitration as well as those with jurisdictional issues. There are a number of reasons matters may be allocated to an interstate member. Generally, there is at least one member from the New South Wales courts who also sits on the Queensland roster for unfair dismissal arbitrations. It also happens that in times of peak workload or when members are on leave, matters may be allocated to members interstate. Some matters can be dealt with on the papers by interstate members and there are members who may elect to list matters via telephone or video conference all of which allow matters to be dealt with across state borders.

\subsection{Established rules and legal change}

Since one of our two research questions is to determine the extent to which judicial decisions are affected by regulatory change, it is appropriate to review the three main statutory regimes governing unfair dismissal protection over the relevant period for our study. Federal (Commonwealth) regulation of unfair dismissals began under the Keating government with the enactment of the 1993 Industrial Relations Reform Act, which utilised the Commonwealth's external affairs power, and was modeled on the International Labour Organisation's Convention on Termination of Employment (Convention 158). Dismissals were defined as unfair if third parties (labour courts and tribunals) could, upon review of the evidence, establish them as being 'harsh, unjust or unreasonable'. A labour court, the Australian Industrial Relations Commission (AIRC) was put in charge of handling unfair dismissal cases and make orders for reinstatement or compensation to unfairly dismissed employees. Australian States, beginning with South Australia in 1972, had already introduced their own dismissal regulations well before Federal law was enacted, and these State provisions continued to be applied after the introduction of the Commonwealth legislation, leaving a complex web of regulations with jurisdictional ambiguities. Many cases were brought in the early years of the Commonwealth's 1993 Act, generating significant protest from employers. The legislation and procedures were refined in the years which followed until a more workable balance appeared to have been achieved under the renamed Workplace Relations Act 1996 (WRA).

The election of the Howard government in 1996 triggered renewed pressure from employer organisations to remove unfair dismissal regulation, especially for small business. When the Howard government achieved control of both Houses of Parliament in 2005, reform of unfair dismissal regulation was announced as a major component of the government's WorkChoices changes, embodied in the Workplace Relations Amendment (Work Choices) Act 2005, which came into force on 26 March 2006. Under WorkChoices (WCH) Commonwealth jurisdiction

\footnotetext{
${ }^{4}$ This information was verified and confirmed in November 2011 through telephone interview with one of Fair Work Australia's Senior Deputy Presidents.
} 
increased significantly as the legislation utilised the Commonwealth's corporations power to supersede State jurisdiction for all employment contracts of incorporated businesses. However, the WorkChoices reforms also considerably reduced the coverage of the laws; businesses employing less than 100 workers were exempted from unfair dismissal claims, scope was reduced for employees making claims on procedural grounds, and a new definition of redundancy as a dismissal for 'genuine operational reasons' (such reasons only had to exist, dismissals need not be required by these operational reasons) ruled out claims many of which would have succeeded under the previous regulatory regime. The then Department of Employment and Workplace Relations estimates that WorkChoices reduced the coverage of protected employees from 6.7 to 3.7 millions, a 45 per cent reduction in coverage Department of Education, Employment and Workplace Relations (2012) and indeed, the number of claims lodged toand arbitrated by labour courts subsequently dropped very substantially between 2006 and 2009 Freyens and Oslington (2013).

After the election of the Rudd/Gillard Labour government in 2007 the WorkChoices legislation was repealed and replaced by the Fair Work Act (FWA) which came into force in July 2009, administered by a new body: Fair Work Australia. Coverage of workplaces by Federal legislation increased further with the transfer of State powers to the Commonwealth by all states except Western Australia. Employees of businesses with less than 100 employees were now once again eligible to claim unfair dismissal. Businesses with less than 15 employees were covered by the Small Business Fair Dismissal Code (a streamlined compliance procedure for business, which arguably facilitates the demonstration of fair dismissal to third parties). Employees of businesses with less than 15 employees also faced a longer qualifying period (one year, compared with 6 months for larger firms) and limited redress provided employers can show they have followed the Code. Protection for workers was increased by the restoration of the older definition of 'genuine redundancy'. In 2013, minor revisions to the Fair Work Act 2009 saw the qualifying period to lodge a claim extended from two to three weeks after the dismissal, and the labour courts renamed the Fair Work Commission. The election of the Abbott government in September 2013 has not yet led to new reforms but the Productivity Commission was recently tasked to conduct an Inquiry into the Workplace Relations Framework (with employment protection featuring prominently as one five areas to be investigated) and is due to report in November 2015. Further insight into the main differences between dismissal regulation under the three regimes can be drawn from the legal literature Stewart (2012), Stewart and Forsyth (2009) and Chapman (2009).

\subsection{Social values and judicial ideology}

A second aim of this paper is to ascertain the degree of ideological bias in the decisions of labour courts. If ideological bias is present in the decision of labour court commissioners, then the composition of courts, which changes regularly through attrition and governmentmade appointments is another channel through which the social values of political parties may influence judicial decisions. Compared to, e.g., civil courts, judicial ideology is likely to play a bigger role in labour courts. As mentioned earlier, in most countries, labour courts are 'quasi-courts' (a hybrid between a court and a public administration) and they operating with weaker standards than common law courts. In Australia, labour court judges arbitrating unfair dismissal disputes apply a 'balance of probabilities' standard, which is much weaker 
than the 'beyond reasonable doubt' standard required of common law judges ruling in Federal courts. Even in very complex cases, it is sufficient that the judge in charge of the case believes that the balance of probabilities weighs slightly more in favour of one of the parties to make a decision conforming to that standard. At some extreme, judges have for instance been able to rule in favour of the employee based upon non-substantive and non-procedural factors (such as the level of hardship faced by the dismissed employee). Although such extreme use of discretionary power is rarely encountered in dismissal dispute decisions, it illustrates well the degree of room for manoeuvre that labour courts judges can call upon relative to a Federal court judge.

Judges' life tenure ${ }^{5}$ and independently-set salaries are important safeguards against ideological influence by other branches of government, but they are not necessarily sufficient to deter political interference. Politicians could still seek to influence judicial processes through punish-and-reward strategies. Punishment may include barring judges' promotions to higher courts or reducing a court's budget and jurisdiction Landes and Posner (1975), Ferejohn and Kramer (2006). Rewards may be paid in markets for political activism ${ }^{6}$ where politicians' demand for conducting policy through judicial rulings meets with judicial supply of ideological rulings ${ }^{7}$. Although constitutional law prevents formal contracts from underwriting transactions between buyers and suppliers of political activism services, political activism may still emerge in courts through investment rather than consumption, which is the concern of this paper. A government could influence judicial processes at entry level by appointing judicial candidates who, through their work history, have signalled an ideological stance compatible with party platforms. The government then appoints best-fit candidates as an investment in policy control Landes and Posner (1975), Hansen (2004). Investing in political activism allows incumbent governments to harness judicial discretion over policy implementation and gain better control over the actual use and relevance of their policies. However, political activism also reduces the probability that the judiciary will protect government policies against their overthrow by a later government of different political persuasion. If judges are politically selected and politically active, policies are more vulnerable to the voting cycle. With the typically high discount rates used in political strategy, the short-run need for policy control and implementation may overcome longer term concerns for policy stability thus motivating ideological appointments. A reasonable assumption is that appointing parties expect their appointees to use their ideological beliefs whenever established rules are insufficient to determine a case ${ }^{8}$. As with most investments, government appointments bear uncertain returns. Judicial appointees may subsequently rule more objectively than expected out of concern for reputation or reluctance to 'falsify' their mandate as objective arbiters Kuran (1990), J.Miceli

\footnotetext{
${ }^{5}$ Tenure increases the opportunity cost of accepting bribes (and increases the predictability of a judge's decisions - Landes and Posner (1975). However, there are exceptions to life tenure. In the United States, most State- and lower courts judges are submitted to the elective principle: they can be voted in or out on a regular basis - although very few ever are (Friedman 2006).

${ }^{6}$ Political activism consists of rulings made to promote the ideological objectives a political party, whether or not it involves new case law. By contrast, judicial activism consists of rulings that create new law or change existing law, whether or not it has underlying political motivation.

${ }^{7}$ By 'ideology' we mean more than principled disagreements about a set of social values and adopt Roemer's (1994 : 327) characterisation as 'different views of how the economy works' put forth with the sole objective of maximising the expected utility of a particular income class.

${ }^{8}$ This is one of the main tenets of the 'attitudinal model' of Segal and Spaeth (1993), which holds that ideology comes into play in 'hard cases'.
} 
and Cosgel (1994), or they may act strategically by not signalling their true ideological stance prior to appointment. Investing in political activism is also risky: public and media scrutiny relays information about blatant or extreme cases of politically motivated appointments to the electorate, which may bring electoral punishment ${ }^{9}$.

The credibility of the judiciary as an institutional control over government power rests on its independence from executive and legislative power (see Kaufman (1980) and Salzberger (1993)). For some, judicial independence is 'the priceless possession of any country under the rule of law' (e.g., Brennan (1996)), protecting fundamental freedoms (e.g., Hayek (1960) and van den Berg (1998)) and the pursuit of economic prosperity (e.g., Feld and Voigt (2003), Porta et al. (2004) and World Bank (2001)). Evidence of politically motivated behaviour amidst the judiciary would therefore be a matter of significant concern for the public interest. Although there is little existing economic modelling of the ideological motivations of judges, there is a considerable amount of legal and political science scholarship on judicial selection and justice appointments in the United States alone, which would be too onerous to summarise here (see Cross (1999).and Booth (2010) for recent reviews). A common assumption in this literature is that judicial decisions are based partly on case characteristics and partly on judge-specific factors Cohen (1992). Amongst the latter, economic research such as J.Miceli and Cosgel (1994) isolates the reputation of judges, which is improved through precedent setting and reversal aversion (a motive for judicial- rather than political activism). In these models reputation is maximised either for its own sake (which in J.Miceli and Cosgel (1994)'s model contributes directly to judges' utility), or as investment into higher court appointment (Cohen (1992)). None of these models suggest any role for political ideology or political economy considerations. Judges need to develop an understanding of society's dominant values and prevailing ideologies in order to interpret legal texts according to the norms of their time, for instance by paying due consideration to criteria such as economic efficiency or work-life balance. Political activism differs from this behaviour by actively implementing the policy platforms of political parties through judicial decisions.

\subsection{The selection effect}

The validity of using trial cases to analyse judge-specific effects or effects from changes in legal standards is often challenged by the fact that litigated cases are only a selected small proportion of all cases. In a seminal contribution, Priest and Klein (1984) suggest that if the parties are well informed about the legal standards applying to their case by the judges and make their decisions to litigate or to settle based on error-free (Ben, error-free?) predictions of their winning probability, under certain conditions, only the most ambiguous cases will end up in courts. In this setting, the observed rate of plaintiff victory converges to half due to self-selection of highly complex cases, a theoretical proposition known as 'the 50 percent rule'. In a divergent expectations setting (preventing settlement), as the variance of the parties' expectation errors approaches zero, the probability of claimant success converges to 50 percent. The 50 percent rule is the limiting case of the selection effect: since only the most

\footnotetext{
${ }^{9}$ The considerable legislative and media attention given to the nomination of Federal and Supreme Courts judges in the US, and scrutiny of their subsequent decisions is a case in point. Few elections are decided by government bias in judicial appointments, but for the purpose of our model it is enough that the probability of losing elections is affected by an extreme appointment. Electoral cost as a discipline device is discussed in Tabellini and Alesina (1990), World Bank (2001) and Hansen (2004).
} 
difficult and therefore unpredictable cases go to trial, cases that are decided by courts are not a random sample of all cases. Therefore, using the outcome of tried disputes to evaluate the effects in judges' decisions of their social value and of reforms to established rules is quite possibly a futile exercise. Trial outcomes tell us little about whether changes to established rules favour claimants, defendants, or neither side because most (if not all) of the response to these legal changes should take place at conciliation and settlement stage, where cases are less complex and therefore more sensitive to changes in contextual and compositional effects Eisenberg (1990). The Priest-Klein model has been tested in a large number of litigation settings, drawing support (e.g., Kessler et al. (1996)) and criticism (e.g., Wittman (1988)), but its influence is such that inferences from any empirical association between measures of legal change and changes in the win-loss percentage have usually been met with scepticism by researchers.

Nevertheless, at least for the following reasons, we believe that either this kind of selection effect, which is likely to exist, is not strong enough so that the influences of the aforementioned changes in statutory laws, or to the social values of judges can still be identified in the analysis of the litigated case outcomes.

Firstly, as argued in recent research, Priest and Klein (1984)'s 50-50 prediction is based upon many (restrictive) assumptions, including the presumption that the parties are perfectly informed about the legal standard applying to their case, and that the error distributions of both parties are the same and symmetric. Klerman and Lee (2014) argue that if there is information asymmetry between the disputing parties or if the prediction error by the parties does not go to zero, case outcomes could indeed be affected by other factors such as the social values of the judges, or changes in legal standards, and the less complex characteristics of the tried cases. In another words, selection effects are partial. They argue that, even taking selection effects into account, valid inferences can still be made from the percentage of plaintiff trial victories. Thus much more can (and should) be inferred from tried cases.

Secondly, empirical findings are often at odds with what Priest and Klein (1984) predict, even though there is a consensus on the presence of selection effects. For example, many studies do found that the plaintiff win rates varied with both case and/or judicial characteristics (e.g., Epstein et al. (2013), Eisenberg and Johnson (1991), and Kulik et al. (2003)) and environment (e.g., business cycle in Siegelman and Donohue III (1995)). It also seems that the extent to which the assumptions of Priest and Klein (1984) model hold varies with the types of cases as well (see for example, Siegelman and Waldfogel (1999)).

Thirdly, we think there may be other factors at play as well: the applicable legal framework (the established rules) may provide an average standard to the parties, but if judges have differing social values (as any theory of political appointments would claim) the standard of a specific judge would not be expected to fall exactly around the average standard set by established rules. Most of the time, individual judge's standards (their interpretation of the law) are unlikely to be exactly the same as the average legal standard. We think this will particularly be likely to happen in our labour court context. As described earlier, as 'quasicourts', many labour courts such as those in Australia operate with weaker standards than common law courts. Therefore, at the stage where a decision to settle or go to trial is made (a decision which has to be made before a judge is allocated to the case) it is not possible for even well-informed parties to know the exact standard that will apply to their case. Parties would face additional uncertainty of predicting the decision standard on top of predicting the 
case itself. And it is hard to assume the uncertainty is symmetric between parties. It is of course still possible to withdraw from court procedures after judge selection is revealed, but two hurdles remain: (i) it could still be impossible to perfectly estimate the judge' specific standard, so prediction errors remain, and (ii) for many claimants, the opportunity cost of dropping the case after rejecting a settlement offer will be too large. If this is the case in practice, then it would be possible for the results of tried cases to be influenced by judges' social values or by legal reforms with the outcome of the cases differing significantly from the 50-50 prediction of the Priest-Klein model.

Furthermore, Priest and Klein's assumption that both parties predict the case's winning probability with equal effectiveness is also too restrictive. In unfair dismissal disputes, it is likely that employers (especially, the larger firms) who are repeat players in these (and other) disputes, have more resources and are more experienced with litigation, are able to better predict the chances of winning the case than claimants who usually are one-shot players. If this is the case, then it provides another reason for court outcomes to differ from 50-50 outcomes. Finally, if there is asymmetric information and experience in predicting outcomes, as claimed by Klerman and Lee (2014). If that is the case, it provides yet another reason to believe that the results from tried cases may be influenced by legal change and judicial ideology, and should differ from 50-50.

After all, and as Klerman and Lee (2014) remind us, even if the assumptions underlying the Priest and Klein (1984) model were correct, the 50-50 prediction remains a limiting result: when its underpinning assumptions hold true, the probability of a case being tried is also zero. In the subsequent analysis, we will test for the selection effect by looking at whether annual claimant success rates are significantly different from $50 \%$ for the whole data set and for each of the three legal regimes considered in this study.

\section{Data}

The data used in our analysis was collected from electronic transcripts documenting the decisions of labour courts (FWA and its predecessor, the Australian Industrial Relations Commission - AIRC) in unfair dismissal disputes. Transcripts are public domain information available from the FWA website. Transcripts record factual information about the defending parties' background and their respective allegations. They also report the testimonies of witnesses and the judge's decision although this information was sometimes difficult to harmonise because judges often report their decisions in different ways. We recorded all cases for which we have a transcript over the period January 2001 - June 2015, which provided us with 2,876 arbitrated claims.

We recorded elementary data such as cases' legal reference, the statutory regime that governs the cases, their lodgement date, the judge's identity, the dates of hire, dismissal, lodgement and judicial decision, the gender and age of the plaintiff, the sector of activity of the employer, the occupational group of the dismissed employee, the type of representation for both sides, alleged reasons for fair or unfair dismissal, and the judge's decision. If the decision is favourable to the employer, we recorded the variable Award as zero, otherwise we recorded it as 1. Detailed variable definitions are listed in Table 1. For the purpose of this paper, we excluded 241 cases where one of the parties failed to appear in court because the outcome of these kinds of cases are highly predictable (absentees always lose the case) and 
it seems that most of these cases started to appear after 2010 (this introducing bias). As the amount of detailed information included in the transcripts varies a great deal, in some cases not all the relevant information was available. We therefore also excluded 124 cases for which the parties' claims could not be determined; 35 cases for which the characteristics of the commissioners are missing, and 248 cases where the key characteristics of the cases are missing. We further drooped five cases which are the only ones ever ruled by the four commissioners involved. This results in 2,223 cases in the sample for analysis (77.3 percent of our initial sample of cases).

To categorise judges according to their likely ideological positions, we used and updated the appendix provided in Southey and Fry (2010), which records the previous work history of judges using public media, parliamentary records, academic literature and online Who's Who searches. Since Southey and Fry's data stops at 2005, we extended their record of judges' work history and political appointment to identify union or employer association backgrounds for the most recent years. Work history consists of whether a judge worked for a union or an employer association prior to their appointment. Judges were recorded as not having an employer or union background if information on the judge's background was available, and this background was not listed. In a small number of cases the background information could not be found at all, in which case the variable was recorded as missing.

\subsection{Descriptive Statistics}

Table 2 presents the descriptive statistics for the key variables used in the analysis, of our subsample (the aforementioned 2,223 observations) as a whole and for each statutory regime. It provides a representative (but not-exhaustive) overview of our data set. For example, about 18 per cent of the trialled cases involved manufacturing businesses, about 23 per cent of the unfair dismissal claimants were occupied in highest skill professions (with skills ranked on a scale from 1 to 5), and about 72 per cent of the claimants at trial stage are male. About one in five case alleges some form of procedural unfairness in the dismissal process by the former employer. On the other hand, in about one third of all cases, employers' major counter-arguments against employee allegations are that the dismissal was for unambiguous substantive reasons, such as gross misconduct. A large majority of the disputing parties are represented in court (71 per cent of employees and 79 per cent of employers, respectively). Geographically, about 64 per cent of the cases are located in New South Wales and Victoria, Australia's two largest and most urbanised States (accounting for 58 percent of the population). The characteristics of the cases also vary to some extent across the different statutory regimes presented in previous sections. In the later years/statutory regimes, less disputes are lodged by manufacturing workers, but more cases are lodged by highest-skill workers. Both employers and employees tend to be less often represented in later years.

Our sub-sample of 2,223 cases was determined by a set of 81 commissioners. The distribution of the number of cases ruled by each commissioner is presented in Figure 1. On average, each commissioner ruled about 27 cases, but this could vary from a few cases by those who are new to the system to over 100 cases by those who have been in the system for very long time per commissioner. The outcome variable at the centre of our analysis is whether the employee is paid compensation or re-instated by the commissioner - i.e. whether a decision is made in favour of the employee. Overall, in about 39 per cent of the cases, the 
81 commissioners' decisions are made in favour of the employees, but this rate varies across different regulatory regimes. In particular, under the more conservative Work Choices regime, employees won a mere 30 per cent of cases. Furthermore, under Work Choice only 8 per cent of cases were lodged for procedural unfairness (relative to 20 percent under other regimes). This is most likely due to Work Choices exempting small and medium-sized firms (SMEs) from unfair-dismissal regulation and SMEs were more often sued by employees on grounds of procedural unfairness than larger firms.

In Table 3, we summarise the rates of employees' court successes over the sample period and under different regimes. We also test the rates of employees' success against 0.5. A few thing could be observed from the table. First, except for the first 3 years over the sample period, the rates of employee success were all significantly lower than 0.5, which is not consistent with what Priest and Klein (1984) predict. Secondly, compared to the earlier WRA regime, the number of cases lodged yearly under the short-lived WCH regime was significantly reduced, but increased dramatically (more than doubled) under subsequent FWA and FWC regimes. Thirdly, employee success rates under FWA/FWC are indeed higher than under WCH but they are lower than under WRA. Thus the media-heralded belief that the FWA/FWC regime favours employees more than other regimes seems unsupported by our data.

It is possible that the rates of employees' success are correlated with who rules the cases. The characteristics of the commissioners are presented in Table 4. We use the appointing government and commissioners' previous association with unions and employers' associations as indicators of their political and ideological tendencies. 73 per cent (59) of the 81 commissioners were appointed by a labour government and the rest by a Coalition (Conservative) government. About 47 per cent of the commissioners have worked for a workers union in their past professional careers; 34 percent of them have previously worked for employers' associations; and a few of them (about 3.7 percent) have had work experiences with both unions and employer associations. It is quite clear that Labour governments tend to appoint commissioners with union backgrounds and Coalition governments tend to appoint commissioners with employer association backgrounds. It can be calculated that, for example, among the Labour-appointed commissioners, 58 percent have unions backgrounds, and among the Coalition-appointed commissioners, 59 per cent have employers' association backgrounds.

Also presented in Table 4 are the proportions of cases awarded to employees. Labour appointees tend to decide slightly more in favour of employees in their decisions. But the variations in the proportions of cases awarded to employees are more apparent when looking at commissioner background-commissioners with a union background and those with no previous union or employer association experiences tend to judge more often in favour of employees.

In addition, the judges are all permanent and they are only replaced when they leave. The proportion of Labour appointed judges, for example, only increases after Labour has in power for a while. In Figure 2, we plot the proportion of Labour appointed judges. We can see that at the beginning of the sample period, when the Coalition government were in power only for 4 years followed 13 years Labour governments, the proportion of Labour appointed judges were over 80 per cent, the highest over the period. The proportion dropped since, to its lowest level in 2008 and 2009, a couple of years after Labour re-took the power in 2007, 
and grew again since. In Figure 2, we also plot the rates of employee success. ${ }^{10}$ It seems that the general trend of the lines are consistent with each other.

\subsection{Testing for randomised matching}

As mentioned earlier, to identify the potential effect of the commissioners on case outcomes (decisions), it is essential to establish randomness in the process allocating cases to commissioners. Even though cases are indeed randomly allocated to the commissioners, many cases are 'conciliated' (settled) before they reach the arbitration stage (a hearing in court). The conciliation and settlement stage is managed by different personnel (other judges, public servants, etc.) than the commissioners eventually in charge of deciding the case in court. If a case fails to settle, conciliators authorise the case to proceed to arbitration (hearing and decision), which is the stage at which the case is matched to the commissioner. However, not all unsettled cases reach arbitration. Many are withdrawn along the way, or informally settled 'under the shadow of the law'. If such case drop-outs are not randomly distributed among commissioners (e.g. some commissioners exerting an influence on the parties so that no hearing takes place) then our analysis would give inconsistent estimates.

We therefore conducted a series of $F$-tests after regressing various case characteristics on commissioner dummies, essentially following the method used by Ashenfelter et al. (1995). If commissioners exerted no undue influence on drop-outs, then the remaining cases reaching arbitration should still remain randomly allocated to commissioners, and commissioner dummies should be expected to have little explanatory power in these regressions. As commissioners by and large operate within the confines of their respective State we conduct these exercises separately for each of the three largest states, New South Wales, Victoria, and Queensland, where a large majority of our cases are located. The tests are conducted separately for each regime to ensure a relatively homogeneous time period. We test for randomness across 10 key variables of our database of cases, and report the number of commissioners (bracketed) and cases for each State and regulatory regime. The explained case characteristics include those of the employees: industry, skill level, and gender; and those relating to the nature and complicity of the cases: whether multiple claims are made by each party, the type of claims by each party, whether they are represented, and whether the case is summary one. The $P$-values of these $F$-tests are presented in Table 5 . The results show that in most of the tests, the null hypothesis that commissioner dummies are not jointly significant is not rejected, which indicates that the cases reaching courts are most probably randomly assigned.

Overall then, the results of our tests comfort us in the belief that labour courts do indeed randomly match cases with commissioners. The results for NSW (the most represented State in our sample) are particularly salient with no significant relationship under either of the four regimes (no occurrence of $5 \%$ level significance). The hypothesis of randomness is not rejected for all but one of our 10 key indicators at the 5\% level, and in two cases the test is rejected at $10 \%$ level. Significance is only slightly more prominent for the other two Australian States. In a few isolated cases (without any consistent pattern) the randomness tests are rejected at the 5\% significant level for Victorian and Queensland cases. For example, under the most

\footnotetext{
${ }^{10}$ The rates of employee success in each year in Figure 2 are a bit different from those in Table 3. This is because in Table 3, the year of dismissal is used as this determines the regime under which the cases are ruled. In Figure 2, the year is 'the year of decision' which is relevant which judges were making the decision.
} 
recent FWA regime in Victoria and in Queensland, for whether the case is summary case, the randomness test is rejected. Given the large number of test conducted, this could well be due to the Type I error. Nevertheless, as a precautionary step, we conduct our analysis using both the full sample and the more restricted, fully-tested NSW sample for which we have full certainty about randomness.

\section{Effects of statutory regimes and judges' background}

\subsection{The model}

Since we observe multiple cases decided by each commissioners, we can construct a panel data of the commissioners. We assume that the decisions of the commissioners are determined both by the characteristics of the cases, of the disputing parties, and of the commissioners themselves. Suppose the outcome of the $j$ th case in year $t$ judged by commissioner $i, Y_{i j t} \in$ $\{0,1\}$ (with $Y_{i j t}=1$ indicating that the employee wins the case), is determined by a range of variables: $D_{i j t}$, a vector of regime dummies; $x_{i j t}$ a vectors of case 'characteristics'; $s_{i}$ a vector of commissioners' observed characteristics; $\mu_{i}$ commissioners' unobserved characteristics; and an idiosyncratic error term $\epsilon_{i j t}$, we specify that the probability for the commissioner delivering a verdict in favour of the employee is given by the following function.

$$
\operatorname{Prob}\left\{Y_{i j t}=1\right\}=F\left(\alpha+x_{i j t}^{\prime} \beta+D_{i j t}^{\prime} \gamma+s_{i}^{\prime} \eta+\mu_{i}\right)
$$

To allow for the possibility that commissioners may behave differently under different regimes, we also include interaction terms between the regimes $(D)$ and some of the characteristics of the commissioners.

The impact of the regimes and the characteristics of the commissioners are captured by or are proportional to the parameters $\gamma$ and $\eta$, depending how the function $F(\cdot)$ is specified. we consider a few model specifications.

First of all, if we assume that $F$ is linear and that the observed explained variables are uncorrelated with the unobserved commissioners' characteristics $\mu$ (and the ideosyncratic error term), the model becomes a linear probability model and can be estimated with OLS.

However, if some of the included explanatory variables are correlated with the error terms, the estimated effects would be inconsistent. This is quite likely since we only observe very limited information on the commissioners. For example, some of their characteristics that are unobserved, e.g., family background, might be correlated with their political inclination. In this case, OLS estimator will be inconsistent. Since we observe multiple cases for each commissioner, we can estimate the standard fixed-effect model to get consistent estimates for $\beta$ and $\gamma$. The drawback is that we are not able to identify the parameters for the time in-variant variable $s_{i}$.

Secondly, alternatively, if we assume $F$ is the standard normal function (or logistic function), and that the observed explained variables are uncorrelated with the unobserved commissioners' characteristics $\mu$ (and the ideocyncratic error term), it becomes a standard Probit (Logit) model. However, it suffers similar problems as the OLS when the unobserved characteristics of the commissioners are correlated with the observed variables. Thus, to take the unobserved heterogeneity problem into account, we estimate Chamberlain (1982)'s conditional logit model (also known as the 'fixed-effect Logit' model). Again, the drawback of 
this estimator is that the impacts of the commissioner characteristics, which is time-invariant, cannot be estimated together with those of the regime.

\subsection{The results}

The results are summarised in Tables 6. In Table 6A, we present the estimated effects of the regimes and commissioners' background on commissioners' decisions of the cases from the full sample using the alternative models mentioned above. The effects of the regimes are captured by the coefficients of the regime variables and their interaction terms with the commissioners' appointing party. The estimates from OLS and probit are very close to one another. The results show that compared to the benchmark WRA regime, it was much less likely that commissioners would award cases to employees under the $\mathrm{WCH}$ regime. These findings are confirmed by the results of the two fixed-effect models. As discussed earlier, the OLS (and Probit) results may be inconsistent due to the potential endogeneity problem of the commissioner background variables. The magnitudes of two fixed effect model estimates are somewhat different from the OLS (and Probit) estimates. However, they are qualitatively similar to the OLS (and probit) estimates. According to the Linear Fixed-effect model, compared to under WRA, the likelihood for a Coalition-appointed commissioners to award the cases to the employees is about 29 per cent less under Work Choice, and that for a Labourappointed commissioner is about 17 per cent less (the sum of the coefficients of WCH and its interaction with Labour-appointee).

The results also show that commissioners' background also plays a role in their judgement. Again, although by which party the commissioners were appointed did not play a role in their judgement under WRA or FWC, the Labour-appointees were more likely to award the cases to the employees under WCH - the coefficient of the interaction term between WCH and Labourappointee is significant in OLS and almost significant in the fixed-effect linear model at 10 per cent level and is similar in magnitudes. Estimates of the probit and fixed-effect logit model are more significant and are slightly larger in magnitude. This seems to suggest that Labourappointed judges were trying and able to 'correct' some unfavourable effects of the regulation to the employees. OLS and Probit give similar estimates on the effect of commissioners' background. Compared to the commissioners who did not have previous experiences in either union or employer associations, the ones who associated with employer associations awarded the cases significantly less likely to the employees-the difference in likelihood is about 10 per cent. Together with the finding that the commissioners with union background behaved similarly to those without previous experiences, this result show that the commissioners from the two camps do make their rulings differently and probably according to their ideological inclinations. We do not find any significant effect of commissioners' gender on the ruling of the cases. We do acknowledge that these estimates of commissioner characteristics effects could be inconsistent if there are omitted variables that are correlated with them. However, given that the OLS estimates of the effects of the time-variant variables are not very different from those from the fixed-effect models, it is plausible that the bias of these estimates may not be large.

In addition to the institutional variables and commissioners' background variables, it seems that commissioners' judgement is influenced strongly by the 'characteristics' of the cases. For example, the likelihood for the employee winning the case is increased by 14 per cent 
(according to the fixed effect model) if she had professional representatives. Her chance of winning is about 14 per cent higher if her main claim was procedural unfairness and about 9 per cent higher for every additional claim she may have. Meanwhile, the employers were more likely (with the chance 16 per cent higher) to be awarded the cases if they have professional representatives or if they gave out very specific reasons for the dismissals (the chance is 17 per cent higher). These results are consistent across all models. These findings are not surprising in that the chance of winning is always higher when the party has a stronger case. For example, a party would probably only hire a representative when she believes the expected payoff to be positive. Interestingly, if the cases are declared to be 'summary dismissal' (about one fifth of all cases) then the probability of employee success in courts is significantly improved. This may a consequence of 'heated' dismissal situations in which the employer forces the employees to leave the premises forthwith but with insufficient attention dedicated to substantiating the reason for the dismissal, or at least justifying why mandated procedures could not be followed in those cases. Note that it is unclear from the documented transcripts whether summary dismissal is identified by the judge or by the parties, but it is reasonable to assume that the judge identifies a dismissal as summary based on information provided by the parties (there is no evidence in the transcripts of the parties arguing about the summary nature of the dismissal).

The finding that the presence of a professional representative for either party significantly affects the success rate may suggest that legal professionals are better able to predict the cases and therefore narrow prediction errors for the parties. Thus prediction capacity differs among the parties, and those who can hire legal professionals are in a better position to succeed. This finding is consistent with our earlier contention that assuming the parties to be equally able to predict the chance of claimant success is a very restrictive aspect of the Priest and Klein model.

As noted in the previous section, in some isolated cases, the tests of random matching of judges to cases are rejected. To check whether the findings are robust we present in table $6 \mathrm{~B}$ our estimates using only the cases for New South Wales - where the random case allocation test is not strongly rejected for any of our key controls. The estimated effects are by and large in line with those from the full sample. The results confirm that the WCH regime has significant negative effects on claimants' success rates. The results also confirm that the effects of commissioners' background on the rulings are significant. Again, the likelihood that the commissioners awarded the cases to the dismissed employee decreased by about 17 per cent if judges had been associated with employers' associations in their past careers. In NSW, we also find that Australian Labour Party appointee effects are much stronger than for the country as a whole, ALP-appointed commissioners are about 14 per cent more likely to award the cases to the employees, and there is no significant difference across different regimes. The estimated coefficients of the other variables remain close to those from the full sample. It is important to note that the number of observations used for the NSW analysis is substantially reduced from 2,223 to around 600. As a consequence, the standard errors of the estimates become larger, which means the estimates are less precisely estimated.

These findings show that the commissioners are not operating in a vacuum, that their judgement is constrained by the institutional environment they operate in (rules) and influenced by their own background (values). The findings also confirm the presence of social value (compositional) effects found by Booth and Freyens (2014) in a much smaller sample of 
cases.

\section{Conclusions}

Our study examined the effects of regulatory intervention on the decision of labour courts arbitrating unfair dismissal disputes, using a database of over 2,000 unfair dismissal cases arbitrated over a 15 year period in Australian labour courts, together with records of judges' employment history and the political colour of the government that appointed them. Specifically, we addressed two questions. First we looked at regulatory reforms to the strictness of unfair dismissal laws. Such reforms make established rules more or less favourable to dismissed employees seeking redress, and we sought to establish how the decisions of labour court judges (commissioners) are subsequently affected, i.e. whether specific statutory regimes predict a significantly different chance of success for claimants. Second, we asked to what extent judges in charge of arbitrating dismissal disputes use their judicial discretion to apply their own social values into their decisions, for instance by deciding more often in favour of the plaintiff. Judges' social values may reflect the prevailing ideology of the political party that appointing them. If that is the case, the identity of the appointing political party and the previous work history of judges would affect the frequency with which judges rule in favour of specific parties to a dismissal dispute.

We counterchecked the natural randomisation of the allocation of cases to judges and tested that judges are indeed, as labour courts allege is their procedure, randomly matched to cases. Our analysis could then exploit the implicit independence between judges and case characteristics, so that judges of different backgrounds and under different regulatory regimes can be presumed to face the same mix of cases over time. We found strong statutory regime effects in the wake of a major and a minor reform to the strictness of unfair dismissal laws.

We found no significant party appointment effects in our four full specification models. Although significant effects had been found in a previous pilot study of 1,004 dismissal cases (Booth \& Freyens 2014) we note that they had only been found in partial specifications. Importantly, interacting Labour party appointment with legal regimes reveal that Labour party appointees decided significantly more in favour of dismissed employee under the employeeadverse $\mathrm{WCH}$ regime than in the other two legal regimes, suggesting possibly that these judges found it their duty to compensate claimants through their decisions for the adversity of the law in that particular context.

On the other hand, judicial candidates' signalled ideology (their work history) significantly predicts decisions favourable to the employer (by about 10 percent), which is also in line with the full specification of the pilot study. Our table 3 shows that the Conservative party, when in government, appoints proportionally more judges who have an employer association background, and our analysis shows that judges with an employer association background are much less likely to find in favour of the employee. Our finding that the chance of success would be substantially increased when the parties hire representatives seem to suggest that legal representatives have a better knowledge of the system and/or the cases. Thus, the assumption by Priest and Klein (1984) that parties could predict the cases equally well is unlikely to be true in a large number of cases.

Our empirical analysis therefore supports our initial conjecture that the frequency with which judges rule in favour of dismissed employees is significantly affected by political mo- 
tivations, and these motivations affect outcomes through reforms to established rules and through nomination bias int he procedures for court appointment. We do not suggest (nor offer evidence) that judges deliberately promote political parties' agendas through their decisions. Instead, we contend that in ideoilogically charged regulatory contexts such as statutory dismissal law where judges interpret rather than make the law and where legal standards are relatively weak, judicial processes are very unlikely to be free of social values and judicial decisions will regularly rest on the ideological stance of the judge. To the extent that judges' true ideological stances are signalled to- and observed by political parties prior to appointment, the correlation between political motivation and judicial rulings emerges from changes in the composition of courts and from changes in the legal standards legislated by governments. Our empirical analysis suggests that these effects were stronger under conservative governments' appointments and legal reforms, but they remain sizeable under Labour governments as well. If judicial independence is indeed 'the priceless possession of nations' these results may raise justified concern about the strength of the judicial institutions examined in this study. 


\section{Figures}

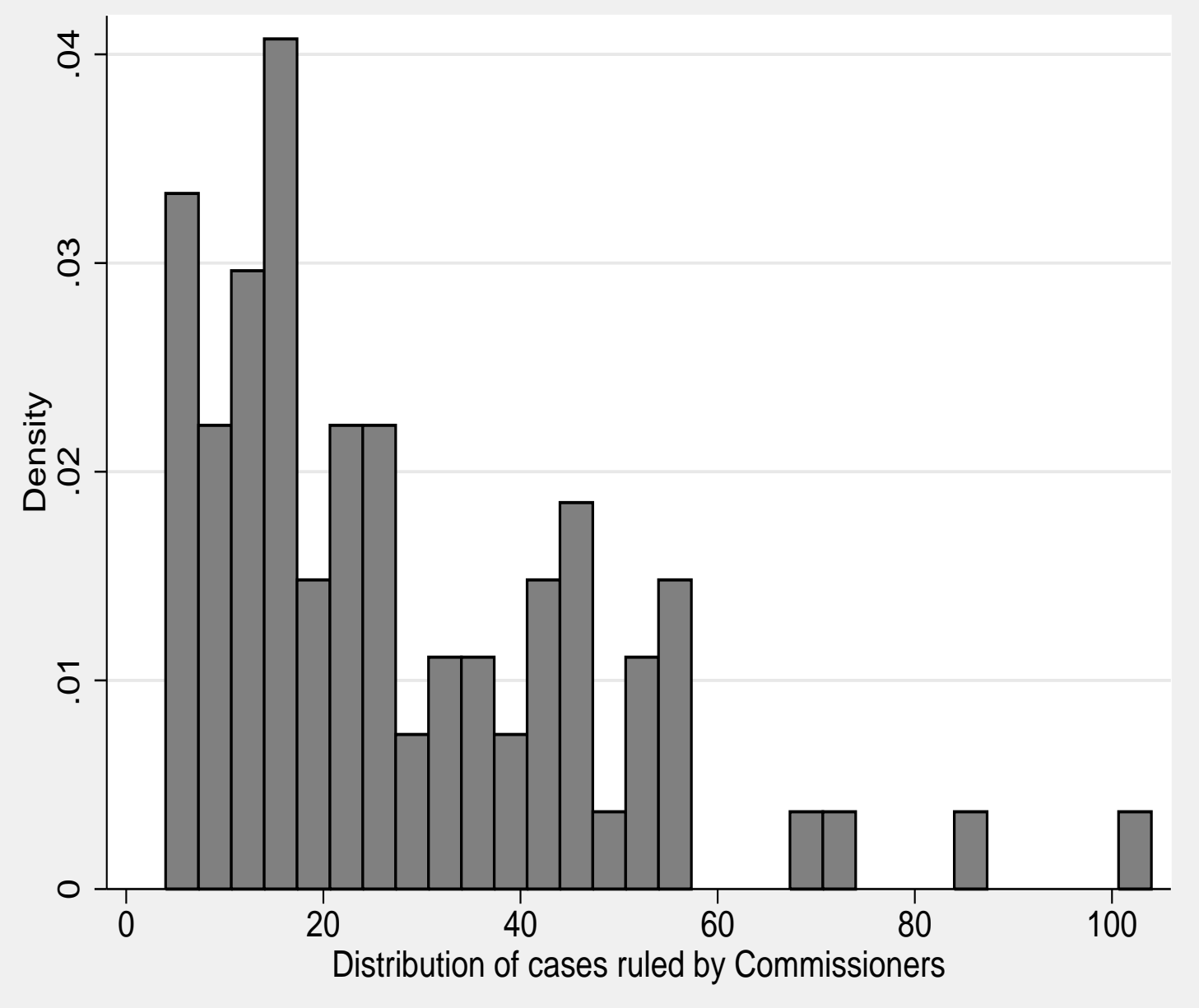

Figure 1. Distribution of court cases ruled by each commissioner 


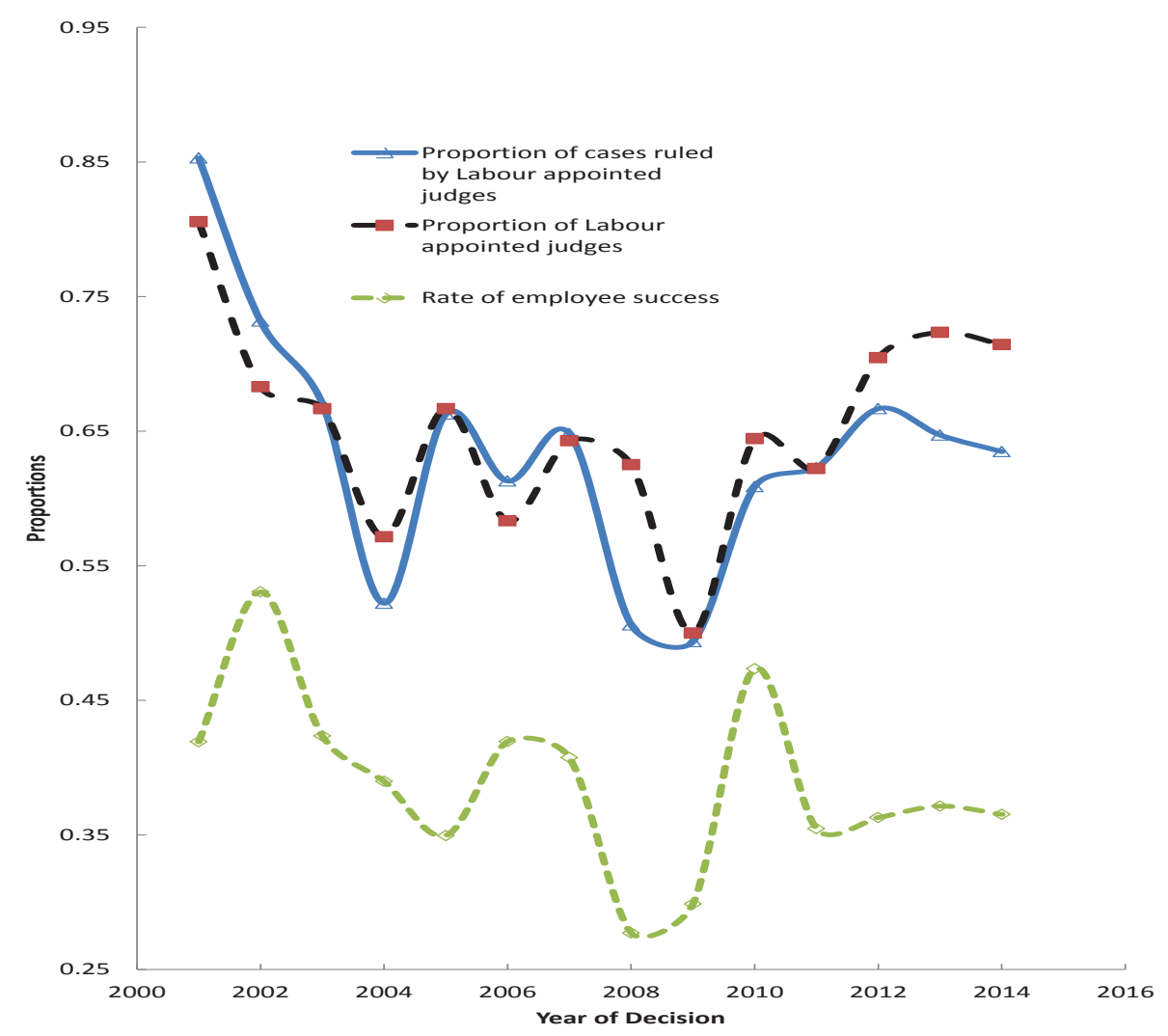

Figure 2. Proportions of Labour appointed judges and of the cases ruled by them 


\section{Tables}

Table 1. Definitions of variables

\begin{tabular}{|c|c|}
\hline award & Dummy, 1 if the employee wins. \\
\hline Most skilled & $\begin{array}{l}\text { Dummy, } 1 \text { if the employee is in the most skilled category } \\
\text { according to ANZCOSKI. }\end{array}$ \\
\hline Manufacture & Dummy, 1 if the employee is in a manufactural sector. \\
\hline $\mathrm{ACT}$ & Dummy, 1 if the case is in Australian Capital Territory. \\
\hline NSW & Dummy, 1 if the case is in New South Wales. \\
\hline NT & Dummy, 1 if the case is in Northern Territory. \\
\hline QLD & Dummy, 1 if the case is in Queensland. \\
\hline SA & Dummy, 1 if the case is in South Australia. \\
\hline TAS & Dummy, 1 if the case is in Tasmania. \\
\hline VIC & Dummy, 1 if the case is in Victoria. \\
\hline WA & Dummy, 1 if the case is in Western Australia. \\
\hline Employee represented & Dummy, 1 if the employee has a representative \\
\hline Employer represented & Dummy, 1 if the employer has a representative \\
\hline 1st allegation employee: procedure & $\begin{array}{l}\text { Dummy, } 1 \text { if the employee's major allegation is on } \\
\text { procedural unfairness rather than substance. }\end{array}$ \\
\hline 1st allegation employer: specified & $\begin{array}{l}\text { Dummy, } 1 \text { if the employer's major allegation is on specific } \\
\text { facts, such as major misconduct, end of probation, etc. }\end{array}$ \\
\hline Multiple allegations by employee & Dummy, 1 if the employee made more than one allegations. \\
\hline Multiple allegations by employer & Dummy, 1 if the employer made more than one allegations. \\
\hline No of allegations by employee & the number of allegations made by the employee. \\
\hline Gender of employee & Dummy, gender of the employee, 1 if male. \\
\hline Summary dismissal & Dummy, 1 if the case is a summary dismissal case \\
\hline
\end{tabular}


Table 2. Sample statistics

\begin{tabular}{lrrrr}
\hline \hline & All & WRA & WCH & FWA \\
award & .393 & .437 & .295 & .383 \\
Most skilled & .226 & .189 & .198 & .254 \\
Manufacture & .180 & .227 & .203 & .146 \\
ACT & .034 & .034 & .041 & .032 \\
NSW & .276 & .239 & .424 & .274 \\
NT & .026 & .043 & .005 & .019 \\
QLD & .135 & .074 & .097 & .179 \\
SA & .063 & .039 & .032 & .084 \\
TAS & .017 & .014 & .018 & .018 \\
VIC & .361 & .508 & .313 & .277 \\
WA & .089 & .050 & .069 & .116 \\
Employee represented & .708 & .886 & .747 & .589 \\
Employer represented & .791 & .885 & .880 & .716 \\
1st claim employee: procedure & .207 & .218 & .078 & .222 \\
1st claim employer: specified & .333 & .364 & .207 & .336 \\
Multiple claims by employee & .550 & .410 & .682 & .614 \\
Multiple claims by employer & .521 & .406 & .696 & .563 \\
No of claims by employee & 1.685 & 1.492 & 1.793 & 1.787 \\
Gender of employee & .718 & .722 & .765 & .708 \\
Summary cases & .225 & .207 & .226 & .236 \\
No of commissioners & 81 & 51 & 38 & 63 \\
No. of cases & 2,223 & 774 & 217 & 1,232 \\
\hline \hline
\end{tabular}

Table 3. Workers's success rate by year and institution

\begin{tabular}{lrrrr}
\hline \hline Year & All & WRA & WCH & FWA \\
2000 & $.410(78)$ & $.410(78)$ & & \\
2001 & $.500(170)$ & $.503(173)$ & & \\
2002 & $.458(131)$ & $.459(135)$ & & \\
2003 & $.395^{* *}(152)$ & $.380^{* *}(158)$ & & \\
2004 & $.368^{* *}(106)$ & $.364^{* *}(107)$ & & \\
2005 & $.427(75)$ & $.436^{* *}(78)$ & & \\
2006 & $.391^{*}(64)$ & $.560(25)$ & & $.438(112)$ \\
2007 & $.338^{* *}(65)$ & & $.282^{* *}(39)$ & $.344^{* *}(64)$ \\
2008 & $.278^{* *}(79)$ & & $.266^{* *}(79)$ & $.374^{* *}(235)$ \\
2009 & $.401^{* *}(147)$ & & $.286^{* *}(35)$ & $.412^{* *}(226)$ \\
2010 & $.412^{* *}(226)$ & & & $.346^{* *}(295)$ \\
2011 & $.374^{* *}(235)$ & & & $.408^{* *}(120)$ \\
2012 & $.373^{* *}(241)$ & & & \\
2013 & $.346^{* *}(295)$ & & & \\
2014 & $.408^{* *}(120)$ & & & \\
Total & $.394^{* *}(2,184)$ & $.435^{* *}(754)$ & $.295^{* *}(217)$ & $.383^{* *}(1,232)$ \\
\hline \hline
\end{tabular}


Table 4. Commissioner Characteristics (\%) and their rate of awards

\begin{tabular}{l|ccccc}
\hline \hline & Union only & Employer only & Union and Employer & None & all \\
\hline Coalition appointees & 3.70 & 14.81 & 1.23 & 7.41 & 27.16 \\
& $(.42)$ & $(.33)$ & $(.0)$ & $(.42)$ & $(.35)$ \\
Labour appointees & 39.51 & 16.05 & 2.47 & 14.81 & 72.84 \\
& $(.44)$ & $(.29)$ & $(.53)$ & $(.50)$ & $(.42)$ \\
All & 43.21 & 30.86 & 3.70 & 22.22 & 100.00 \\
& $(.44)$ & $(.31)$ & $(.35)$ & $(.47)$ & $(.40)$ \\
\hline \hline
\end{tabular}

Obs. 81 commissioners.

The proportion of the cases awarded to the employees are in the parentheses.

Table 5A. $P$-values of $F$-Tests for random assignment of the cases (NSW)

\begin{tabular}{l|rrr}
\hline \hline & WRA & WCH & FWA \\
\hline No of Commissioners & $(16)$ & $(14)$ & \\
Multiple claims by employee & .238 & .686 & $.25)$ \\
Multiple claims by employer & .209 & .769 & .410 \\
Gender of employee & .479 & .788 & .404 \\
Manufacture & .184 & .582 & .189 \\
Occupation & .562 & .479 & .327 \\
Most skilled & .545 & .228 & $.067^{*}$ \\
Employer represented & .543 & .579 & .114 \\
Employee represented & .577 & .979 & $.040^{* *}$ \\
1st claim employee: procedure & .668 & .906 & $.083^{*}$ \\
1st claim employer: specified & .151 & .925 & .749 \\
Summary cases & .232 & .707 & .121 \\
no of cases & 185 & 92 & 337 \\
\hline \hline
\end{tabular}

** Significant at $5 \%$ level; ${ }^{*}$ Significant at $10 \%$ level.

Table 5B. $P$-values of $F$-Tests for random assignment of the cases (VIC)

\begin{tabular}{l|rrrr}
\hline \hline & WRA & WCH & FWA & \\
\hline No of judges & $(34)$ & $(16)$ & & $(21)$ \\
Multiple claims by employee & .236 & .389 & .698 \\
Multiple claims by employer & .156 & $.006^{* *}$ & .311 \\
Gender of employee & .317 & .645 & .304 \\
Manufacture & .934 & .154 & .594 \\
Occupation & .346 & .962 & .277 \\
Most skilled & $.021^{* *}$ & .700 & .481 \\
Employer represented & .162 & .921 & .496 \\
Employee represented & .155 & .968 & .041 \\
1st claim employee: procedure & .436 & .931 & .552 \\
1st claim employer: specified & .178 & .542 & $.042^{* *}$ \\
Summary cases & .755 & .860 & $.002^{* *}$ \\
no of cases & 393 & 68 & 341 \\
\hline \hline
\end{tabular}

** Significant at $5 \%$ level; * Significant at $10 \%$ level. 
Table 5C. $P$-values of $F$-Tests for random assignment of the cases (QLD)

\begin{tabular}{l|rrrr}
\hline \hline & WRA & WCH & FWA \\
\hline No of judges & $(5)$ & $(4)$ & & $(13)$ \\
Multiple claims by employee & .130 & .180 & .258 \\
Multiple claims by employer & .126 & .862 & & .585 \\
Gender of employee & .295 & .851 & .237 \\
Manufacture & .824 & .412 & $.056^{*}$ \\
Occupation & .843 & .690 & .125 \\
Most skilled & .336 & .851 & .211 \\
Employer represented & .664 & $.054^{*}$ & .238 \\
Employee represented & .999 & .180 & .201 \\
1st claim employee: procedure & .541 & .233 & $.064^{*}$ \\
1st claim employer: specified & .498 & .851 & .242 \\
Summary cases & .666 & .439 & $.001^{* *}$ \\
no of cases & 57 & 21 & 221 \\
\hline \hline
\end{tabular}


Table 6A. Estimation results (full sample)

\begin{tabular}{|c|c|c|c|c|}
\hline & OLS & Fixed effect linear & Probit & Fixed effect logit \\
\hline \multirow[t]{2}{*}{ FWA } & -.176 & -.172 & -.187 & -.206 \\
\hline & {$[-0.86]$} & {$[-0.84]$} & {$[-0.93]$} & {$[-0.93]$} \\
\hline \multirow[t]{2}{*}{ WCH } & $-.323^{* *}$ & $-.292^{* *}$ & $-.343^{* *}$ & $-.323^{* *}$ \\
\hline & {$[-3.00]$} & {$[-2.55]$} & {$[-2.96]$} & {$[-2.47]$} \\
\hline \multicolumn{5}{|l|}{ Commissioner Characteristics } \\
\hline \multirow[t]{2}{*}{ Gender } & .014 & & .016 & \\
\hline & {$[0.33]$} & & {$[0.40]$} & \\
\hline \multirow[t]{2}{*}{ Labour appointee } & .027 & & .025 & \\
\hline & {$[0.58]$} & & {$[0.56]$} & \\
\hline \multirow[t]{2}{*}{ Union background only } & -.016 & & -.017 & \\
\hline & {$[-0.38]$} & & {$[-0.42]$} & \\
\hline \multirow[t]{2}{*}{ Employer association only } & $-.100^{* *}$ & & $-.098^{* *}$ & \\
\hline & {$[-2.47]$} & & {$[-2.49]$} & \\
\hline \multirow[t]{2}{*}{ Union and Employer association } & .041 & & .039 & \\
\hline & {$[0.34]$} & & {$[0.33]$} & \\
\hline \multirow{2}{*}{ Labour appointee $\times$ FWA } & .009 & .036 & 011 & .042 \\
\hline & {$[0.14]$} & {$[0.57]$} & {$[0.18]$} & {$[0.61]$} \\
\hline \multirow[t]{2}{*}{ Labour appointee $\times \mathrm{WCH}$} & $.126^{*}$ & .121 & $.153^{* *}$ & $.152^{*}$ \\
\hline & {$[1.77]$} & {$[1.62]$} & {$[2.16]$} & {$[1.82]$} \\
\hline \multicolumn{5}{|l|}{ Case characteristics } \\
\hline \multirow[t]{2}{*}{ Employee represented } & $.128^{* *}$ & $.136^{* *}$ & $135^{* *}$ & $.160^{* *}$ \\
\hline & {$[5.83]$} & {$[5.73]$} & {$[5.87]$} & {$[6.22]$} \\
\hline \multirow[t]{2}{*}{ Employer represented } & $-.162^{* *}$ & $-.156^{* *}$ & $-.164^{* *}$ & $-.180^{* *}$ \\
\hline & {$[-6.91]$} & {$[-6.07]$} & {$[-7.61]$} & {$[-6.13]$} \\
\hline \multirow[t]{2}{*}{ 1st claim employee: procedure } & $.137^{* *}$ & $.136^{* *}$ & $.134^{* *}$ & $.149^{* *}$ \\
\hline & {$[6.39]$} & [5.60] & {$[6.72]$} & {$[5.83]$} \\
\hline \multirow[t]{2}{*}{ 1st claim employer: specified } & $-.170^{* *}$ & $-.172^{* *}$ & $-.168^{* *}$ & $-.191^{* *}$ \\
\hline & {$[-6.31]$} & {$[-8.11]$} & {$[-6.32]$} & {$[-7.93]$} \\
\hline \multirow[t]{2}{*}{ No of claims by employee } & $.095^{* *}$ & $.093^{* *}$ & $.094^{* *}$ & $.104^{* *}$ \\
\hline & {$[7.34]$} & {$[6.40]$} & {$[7.59]$} & [7.00] \\
\hline \multirow[t]{2}{*}{ Gender of Employee } & $-.040^{*}$ & $-.048^{* *}$ & $-.039^{*}$ & $-.054^{* *}$ \\
\hline & {$[-1.66]$} & {$[-2.04]$} & {$[-1.70]$} & {$[-2.08]$} \\
\hline \multirow[t]{2}{*}{ Summary cases } & $.145^{* *}$ & $.140^{* *}$ & $.137^{* *}$ & $.147^{* *}$ \\
\hline & {$[5.07]$} & {$[5.87]$} & {$[5.27]$} & {$[5.80]$} \\
\hline Skill level & \multicolumn{4}{|c|}{ yes } \\
\hline Industry & \multicolumn{4}{|c|}{ yes } \\
\hline year dummies & \multicolumn{4}{|c|}{ yes } \\
\hline State & \multicolumn{4}{|c|}{ yes } \\
\hline Obs & 2,223 & 2,223 & 2,2223 & 2,214 \\
\hline
\end{tabular}

Reference groups: the regime of WRA, and commissioners

who had neither union or employer association background.

For Probit and Fixed effect Logit models, presented are the marginal effects.

$t$-values calculated are in the brackets. Robust standard errors are for OLS and Probit.

** Significant at $5 \%$ level; * Significant at $10 \%$ level. 
Table 6B. Estimation results (NSW cases only)

\begin{tabular}{|c|c|c|c|c|}
\hline & OLS & Fixed effect linear & Probit & Fixed effect logit \\
\hline \multirow[t]{2}{*}{ FWA } & -.133 & -.016 & -.183 & -.026 \\
\hline & {$[-0.35]$} & {$[-0.05]$} & {$[-0.59]$} & {$[-0.11]$} \\
\hline \multirow[t]{2}{*}{$\mathrm{WCH}$} & $-.337^{*}$ & -.302 & $-.322^{*}$ & -.196 \\
\hline & {$[-1.94]$} & {$[-1.57]$} & {$[-1.67]$} & {$[-1.17]$} \\
\hline \multicolumn{5}{|l|}{ Commissioner Characteristics } \\
\hline \multirow[t]{2}{*}{ Gender } & -.084 & & -.078 & \\
\hline & {$[-1.22]$} & & {$[-1.19]$} & \\
\hline \multirow[t]{2}{*}{ Labour appointee } & $.139 * *$ & & $.168^{* *}$ & \\
\hline & {$[3.03]$} & & {$[2.65]$} & \\
\hline \multirow[t]{2}{*}{ Union background only } & .051 & & .048 & \\
\hline & {$[0.88]$} & & {$[0.89]$} & \\
\hline \multirow[t]{2}{*}{ Employer association only } & $-.167^{* *}$ & & $-.170^{*}$ & \\
\hline & {$[-2.92]$} & & {$[-3.20]$} & \\
\hline \multirow[t]{2}{*}{ Union and Employer association } & $-.197 * *$ & & $-.201^{* *}$ & \\
\hline & {$[-2.14]$} & & {$[-2.54]$} & \\
\hline \multirow{2}{*}{ Labour appointee $\times$ FWA } & -.091 & -.160 & -.118 & -.150 \\
\hline & {$[-1.24]$} & {$[-1.28]$} & {$[-1.40]$} & {$[-1.45]$} \\
\hline \multirow[t]{2}{*}{ Labour appointee $\times \mathrm{WCH}$} & -.023 & -.022 & -.043 & -.041 \\
\hline & {$[-0.20]$} & {$[-0.17]$} & {$[-0.33]$} & {$[-0.39]$} \\
\hline \multicolumn{5}{|l|}{ Case characteristics } \\
\hline \multirow[t]{2}{*}{ Employee represented } & $.131^{* *}$ & $.134^{* *}$ & $.131^{* *}$ & $.107^{* *}$ \\
\hline & {$[3.12]$} & {$[2.87]$} & {$[3.16]$} & {$[2.63]$} \\
\hline \multirow[t]{2}{*}{ Employer represented } & $-.144^{* *}$ & $-.154^{* *}$ & $-.145^{* *}$ & $-.125^{* *}$ \\
\hline & {$[-3.09]$} & {$[-2.85]$} & {$[-3.29]$} & {$[-2.08]$} \\
\hline \multirow[t]{2}{*}{ 1st claim employee: procedure } & $.150^{* *}$ & $.158^{* *}$ & $.148^{* *}$ & $.124^{* *}$ \\
\hline & {$[3.43]$} & {$[3.11]$} & {$[3.66]$} & {$[2.59]$} \\
\hline \multirow[t]{2}{*}{ 1st claim employer: specified } & $-.142^{* *}$ & $-.159^{* *}$ & $-.137^{* *}$ & $-.126^{* *}$ \\
\hline & {$[-2.49]$} & {$[-3.88]$} & {$[-2.49]$} & {$[-2.42]$} \\
\hline \multirow[t]{2}{*}{ No of claims by employee } & $.094^{* *}$ & $.093^{* *}$ & $.092 * *$ & $.071^{* *}$ \\
\hline & {$[3.62]$} & {$[3.22]$} & {$[3.86]$} & {$[2.82]$} \\
\hline \multirow[t]{2}{*}{ Gender of Employee } & -.014 & -.032 & -.021 & -.036 \\
\hline & {$[-0.26]$} & {$[-0.69]$} & {$[-0.42]$} & {$[-0.90]$} \\
\hline \multirow[t]{2}{*}{ Summary cases } & $.101^{* *}$ & $.079^{*}$ & $.088^{* *}$ & .048 \\
\hline & {$[2.96]$} & {$[1.80]$} & {$[2.69]$} & [1.30] \\
\hline Skill level & \multicolumn{4}{|c|}{ yes } \\
\hline Industry & \multicolumn{4}{|c|}{ yes } \\
\hline Obs & 614 & 614 & 614 & 599 \\
\hline
\end{tabular}

Reference groups: the regime of WRA, and commissioners

who had neither union or employer association background.

For Probit and Fixed effect Logit models, presented are the marginal effects.

$t$-values calculated are in the brackets. Robust standard errors are for OLS and Probit.

** Significant at $5 \%$ level; * Significant at $10 \%$ level. 


\section{References}

Addison, J. and Teixeira, P. (2003). The economics of employment protection. Journal of Labor Research, 24(1):85-129.

Ashenfelter, O., Eisenberg, T., and Schwab, S. J. (1995). Politics and the judiciary: The influence of judicial background on case outcomes. Journal of Legal Studies, 24:257-281.

Bertola, G. (1999). Microeconomic perspectives on aggregate labour markets. In Ashenfelter, O. and Card, D., editors, Handbook of Labour Economics, chapter I, pages 2985-3028. North Holland, Amsterdam.

Booth, J. F. (2010). Judicial activism from a law and economics perspective: Party effects and partisan abuse. mimeo, Research School of Economics and Centre for Law \& Economics, Australian National University.

Booth, J. F. and Freyens, B. P. (2014). A study of political activism in labour courts. Economic Letters, 123(3):370-373.

Brennan, G. (1996). Judicial independence. opening address. Australian Judicial Conference, Canberra, 2 November 1996, Available at http://www.jca.asn.au/attachments/brennan.html.

Buechtemann, C. (1993). Introduction. In Employment Security and Labor Market Behavior; Interdisciplinary Approaches and International Evidence, chapter I, pages 3-66. ILR Press, Ithaca, New York.

Chamberlain, G. (1982). Analysis of covariance with qualitative data.

Chapman, A. (2009). Unfair dismissal law and work choices: From safety net standard to legal privilege. Economic and Labour Relations Review, 16(2):225-238.

Cohen, M. A. (1992). The motives of judges: Empirical evidence from antitrust sentencing. International Review of Law and Economics, 12(1):237-264.

Cross, F. B. (1999). The judiciary and public choice. Hastings Law Journal, 50(2):355-371.

Department of Education, Employment and Workplace Relations (2012). Towards more productive and equitable workplaces - an evaluation of the fair work legislation. Ch. 9 Unfair Dismissal, pp. 209 - 231. Available at https://employment.gov.au/ fair-work-act-review.

Eisenberg, T. (1990). Testing the selection effect: A new theoretical framework with empirical tests. Journal of Legal Studies, 19(2 (Part 1)):337 - 358.

Eisenberg, T. and Johnson, S. L. (1991). The effects of intent: Do we know how legal standards work? Cornell Law Review, 76(6):1151-1197.

Emerson, M. (1988). Regulation or deregulation of the labour market: Policy regimes for the recruitment and dismissal of employees in the industrialised countries. European Economic Review, 32(4):775-817. 
Epstein, L., Landes, W. M., and Posner, R. A. (2013). he Behavior of Federal Judges. Harvard University Press, Cambridge.

Feld, L. P. and Voigt, S. (2003). Economic growth and judicial independence: Cross-country evidence using a new set of indicators. European Journal of Political Economy, 19(3):497527.

Ferejohn, J. A. and Kramer, L. D. (2006). Judicial Independence in a Democracy: Institutionalizing Judicial Restraint. Cambridge University Press, Cambridge, UK.

Freyens, B. P. and Oslington, P. (2013). A first look at incidence and outcomes of unfair dismissal claims under fair work, work choices and the workplace relations act. Australian Journal of Labour Economics, 16(2):295-306.

Gavin, M. (1986). Labor market rigidities and unemployment: the case of severance costs. Board of Governors of the Federal Reserve System.

Hansen, F. A. (2004). Is there a politically optimal level of judicial independence? American Economic Review, 94(3):712-729.

Hayek, F. (1960). The Constitution of Liberty. University of Chicago Press.

J.Miceli, T. and Cosgel, M. M. (1994). Reputation and judicial decision-making. Journal of Economic Behavior \& Organization, 23(1):31-51.

Kaufman, I. R. (1980). The essence of judicial independence. Columbia Law Review, 80(4):671-701.

Kessler, D., Meites, T., and Miller, G. P. (1996). Explaining deviations from the fifty percent rule: A multimodal approach to the selection of cases for litigation. The Journal of Legal Studies, 25(1):233-259.

Klerman, D. and Lee, Y.-H. A. (2014). Inferences from litigated cases. Journal of Legal Studies, 43(2):209-248.

Kulik, C. T., Perry, E. L., and Pepper, M. B. (2003). Here comes the judge: The influence of judge personal characteristics on federal sexual harassment case outcomes. Law and Human Behavior, 27(1):69-86.

Kuran, T. (1990). Private and public preferences. Economics and Philosophy, 6(1):1-26.

Landes, W. M. and Posner, R. P. (1975). The independent judiciary in an interest-group perspective. Journal of Law EG Economics, 18(3):875-901.

Porta, R. L., de Silanes, F. L., Pop-Eleches, C., and Shleifer, A. (2004). Judicial checks and balances. Journal of Political Economy, 112(2):445-470.

Priest, G. L. and Klein, B. (1984). The selection of disputes for litigation. Journal of Legal Studies, 13(1):1-55. 
Salzberger, E. (1993). A positive analysis of the doctrine of separation of powers, or why do we have an independent judiciary? International Review of Law and Economics, 13(2):349379 .

Segal, J. A. and Spaeth, H. J. (1993). The Supreme Court and the Attitudinal Model. Cambridge University Press, Cambridge, UK.

Siegelman, P. and Donohue III, J. J. (1995). he selection of employment discrimination disputes for litigation: Using business cycle effects to test the priest-klein hypothesis. Journal of Legal Studies, 24(2):427-462.

Siegelman, P. and Waldfogel, J. (1999). Toward a taxonomy of disputes: New evidence through the prism of the priest/klein model. Journal of Legal Studies, 28(1):101-130.

Skedinger, P. (2010). Employment Protection Legislation. Edward Elgar, Cheltenham.

Southey, K. and Fry, S. (2010). Stacking the commission: Has it occurred and does it matter in unfair dismissal arbitration? Sydney, 3-5 February 2010.

Stewart, A. (2012). Australian labour law in transition: The impact of the fair work act. New Zealand Journal of Employment Relations, 37(1):3-21.

Stewart, A. and Forsyth, A. (2009). Fair Work: the new workplace laws and the Work Choices legacy. Federation Press, Annandale, NSW.

Tabellini, G. and Alesina, A. (1990). Voting on the budget deficit. American Economic Review, 80(1):37-49.

van den Berg, G. J. (1998). Basic principles on the independence of the judiciary. United Nations' General Assembly resolutions 40/32 of 29 November 1985 and 40/146 of 13 December 1985, accessed 22/09/12 at http://http://www2.ohchr.org/english/law/ indjudiciary.htm.

Verkerke, J. (2009). The law and economics of discharge. In Dau-Schmidt, K. G., Harris, S., and Lobel, O., editors, Labor and Employment Law and Economics, chapter I6, pages 447-479. Edward Elgar, Cheltenham.

Wittman, D. (1988). Dispute resolution, bargaining, and the selection of cases for trial: A study of the generation of biased and unbiased data. The Journal of Legal Studies, $17(4): 315-352$.

World Bank (2001). Judicial independence: What it is, how it can be measured, why it occurs? Brief prepared by M. Stephenson, Harvard University [Online]. Available at http: //www.worldbank.org/publicsector/legal/judicialindependence.htm2001. 